\title{
Handlooms Micro-enterprises for Empowerment of Women in Meghalaya
}

\author{
Anupama Mishra, Puspita Das* and W. S. N. Sangma \\ Department of Textile and Apparel Designing, College of Community Science, CAU, Tura, \\ Meghalaya, India \\ *Corresponding author
}

A B S T R A C T

Keywords

Micro-

entrepreneurs, Handloom, Women weavers, Women empowerment, Rural non-farm activity

\section{Article Info}

\section{Accepted:}

15 December 2020 Available Online: 10 January 2021

\begin{abstract}
Women entrepreneurship is gaining importance all over the world for addressing the development issues of women. Women-owned micro, small and medium enterprises (MSMEs) are contributing significantly towards the economic development of the nation through employment and income generation, poverty eradication and by bringing entrepreneurial diversity in the economic activities. Meghalaya handloom industry offers an appropriate setting to analyse the significance of the rural women-owned microenterprises towards local economic development. Women weavers though largely dominated the handloom sector, with changing market structure and competition; they face most of the difficulties when confronted with the task of finding inspirations for making varieties of textiles. From the survey it becomes apparent that there is dire need for design intervention to enhance the economic viability of existing woven products. The present article traces the issue of women weavers and offers suggestions to overcome them for the wellbeing of women weavers and to analyses the factors that affect tribal women to own a handloom micro-enterprisein Meghalaya.
\end{abstract}

\section{Introduction}

The empowerment of women is crucial for the development of any nation. It is a dynamic and multi-dimensional process in which women challenge the existing norms and culture, to effectively promote their rights and their well-being. It is also a process of awareness and capacity building leading to greater participation, to greater decision making power and control and transformative action. The handloom sector has long been a traditional occupation for women. In primitive society, where the men were hunters and warriors, the women were concerned with food gathering and sustaining agriculture. Women then started producing several crafts like pot, leather clothing, house building and techniques of cordage weaving. Cordage weaving was the beginning of whole chain of our great tradition of woven textiles (4).

In a time where the focus has been on promotion of major industries, it is depressing to see the downfall of such works of art that showcase the traditional cultural values of the weavers. It is important to acknowledge that the hand-woven clothing plays a substantial 
role in making the social and cultural identity of any community in addition to fulfilling the basic clothing needs at home or for ceremonial occasion, especially in North Eastern Regions (NERs). Though all the tribes in Meghalaya produce handloom products, some of them are known for their expertise. For instances, weaving is a full time job for the women particularly, Garo and Hajong women in Meghalaya. Apatani women from Arunachal are famous for weaving 'Galo'. Assamese of Sualkuchi village in Assam, are known for its tradition of weaving silk products (5).

The textile industry is the second largest sector in India in terms of employment, next to agriculture. Out of the 38.47 lakh adult weavers and allied workers in India, 77.9percent are female and 22.1percent are male. Weaving is major source of livelihood for rural tribal women in industrially backward states of NER. The adult women weavers from NERs constitute 49percent of total adult women weavers in India. In the subsequent Handloom Census, an increase in the number of such households has been observed. For the NER, the first Handloom Census accounted for 14.6 lakh households involved in weaving while the third accounted for 15.1 lakh such households. This is in contrast to the national trend of falling total weavers in rest of India. Moreover, women weavers of NER multitask as both handloom producers and traders, thus paving a path towards economic empowerment $(1,14)$.

Handloom sector has occupied an important position in providing employment opportunities to rural women in NER. This sector has created means of livelihood for these women and their families. Recently, Non-Governmental Organisations (NGOs) and even the governments have taken keen interest in promoting the process and providing financial support that would help them create/setup business ventures. Through the support extended by NGOs, Banks and GoI, the women have created Self-Help Groups and Cooperatives thus building a platform for generating income and inculcating entrepreneurial skills. Eventually, this has strengthened their ability to achieve increased control, enhanced their participation in decision making process and developed their level of confidence. As a result, this has established empowerment of women in true sense. And it is for this reason that the governments should promote handlooms with a special focus on transferring the lion share of the revenue generated from sale of handloom products to the weavers(6).

The main objectives of this study include to facilitating an enabling environment for overall development of women weavers in difficult circumstances. Highlighting important issues related to women weavers in Meghalaya. And also identifying appropriate solutions for overcoming the issues of women weavers.

Women weavers, down the ages, have taken pride in passing on their skill to their succeeding generations. In fact, a very clear view on this and considered handicrafts to be a vital part of education. This is a descriptive study based on secondary data. The secondary data required for the paper is collected through published material such as government reports, plan documents, articles and reference books etc. The study limits itself to women weaver's issues and focuses on suggesting solutions to solve their problems.

Empowerment of women means their capacity to participate as equal partners in cultural, social, economic and political systems of a society. It is the creation of an environment where women can make independent decisions on their personal 
development as well as shine as equals in society. Women want to be treated as equals so much so that if a woman rises to the top of her field it should be a commonplace occurrence that draws nothing more than a raised eyebrow at the gender. This can only happen if there is a channelized route for the empowerment of women.

In Meghalaya and NE region the education of a woman is much higher comparatively with other states. Still gender bias and beliefs are playing as chief obstacles for the growth of women empowerment. Thus it is no real surprise that women empowerment in India is a hotly discussed topic with no real solution looming in the horizon except to doubly redouble our efforts and continue to target the sources of all the violence and ill-will towards women (8).

\section{Handloom sector in India}

Handloom industry is the oldest industry. Handloom industry in India is the second largest employer after agriculture. The Indian handloom industry has occupied an important position in respect of its export to foreign countries from an early period. Majority of the handloom weavers in India are selfemployed artisans who are carrying on their profession in their own houses with the assistance of their family members in preloom and post-loom processes. Handloom sector has been catering to the clothing needs of India, and various other countries for centuries altogether. Modern textile industry has grown on this sector, through mechanization and modernization. However, the most modern industry follows the principles of weaving set by the traditional handloom weaver.

Handloom sector, predominately a rural occupation, is one of the largest generators, next to agriculture in India. Nearly 23.77 Lakh handlooms provide direct and indirect employment to 43.32 lakh weavers and allied workers, of which 36.33 lakh workers stay in rural areas and 6.98 workers stay in urban areas and 38.47 lakh adult persons are engaged in weaving and allied activities in the country, out of which, $77.90 \%$ are women. $10.13 \%$ are scheduled tribes, $18.12 \%$ belongs to scheduled castes, and $45.18 \% \mathrm{OBC}$ and $26.57 \%$ are from other castes (8) (Handloom Census, 2013). There are number of factors that have contributed to such resilience. Principal among them is that the weaving is household profession, passed on through generations. In these households, women play an important role. Women weavers have been the principal stabilization force through years of crises and problems for the handloom sector.

The rural non-farm micro-entrepreneurial activities in the informal sector hold significance in generating employment, removing poverty, and income inequality. While meeting the developmental goals, an entrepreneur's risk bearing capacity is regarded as an essential characteristic which distinguishes him/her from the other individuals in the field of entrepreneurship. The handloom industry in India holds a distinctive place in the Indian informal sector as it is the second largest provider of rural employment after agriculture. However, the removal of trade restrictions in the textile sector from January 1, 2005, infused greater competition among the Asian countries like China, India, Bangladesh, Vietnam, Sri Lanka and others to expand their market share. As a result, the Indian handloom industry, which is a part of the textile industry, faced severe competition. The handloom industry in North East India (known as handloom reservoir) is no exception due to numerous problems such as obsolete technologies, unorganized production system, low productivity, inadequate working capital, conventional product range, weak market linkages. Considering the situation, new approaches to 
entrepreneurial activities such as modern technology adoption, scaling up of different production activities, employment of skilled personals, improvement of business network, etc., have become crucial for entrepreneurial performance with the increased market challenges (15). There exists heterogeneity in the performance of micro-enterprises such as that in the handloom firms in terms of investment, production, marketing, etc., where the variation in risk attitude, especially for the financial risk at individual level play a major role. Thus, there is a need to study how individual's attitude towards financial risk takes shape and what are the responsible factors for such variations. From a gender perspective, the females dominate the total handloom workforce but have a lower participation rate in entrepreneurial activities in the handloom industry in North East India $(12,15)$. Moreover, there exists a gender difference in firm performance in the industry, and male-owned firms exhibit a better performance (12).

\section{Women Weavers and Handloom Sector}

Meghalaya handloom sector is only the manufacturing sector wherein one finds large number of women producing products which are worn by large number of women. Women producing for women are a unique feature of the handloom sector. Despite such features, which are outwardly unique, women weavers were never given the primacy they require. Their role in production was never acknowledged beyond the confines of the home. Their work most often went unpaid. Governments never recognized formally as a target group. Even the private initiatives of NGOs, or fashion boutiques, tend to ignore their contribution and role. The most radical to rightist political mobilization structures in handloom sector are devoid of any issues and participation of women $(10,12)$.
Women constitute a major workforce in the handloom sector. Also, most of the handloom products are meant for women. Thus, handloom sector is the unique sector, wherein 60 percent of the women produce almost 70 percent of women products. However, their working, living and wage conditions need to be improved. They need to be empowered in various ways. Almost all the government schemes, projects and programmes on handloom sector have been and continue to bypass this major workforce through various means. They do not have identity cards, which are the principal means through which government welfare measures are sought to be implemented $(9,7)$.

Weaving is an ancient craft of the tribal of Meghalaya. It has a rich variety of handwoven textiles, with unique characteristics that reflect the state and its skilled artisans. The state produces three varieties of silk - Eri (locally known as ryndia from the castor plants the silkworms feed on), Muga and Mulberry. Weaving specimens from the various districts of Meghalaya comprise a wide range and number which themselves as pieces of the precious treasures showing in respect of designing and processing, an accomplishment of great measure.

Spinning and weaving in Meghalaya is the exclusive monopoly of women. Weaving is a full time job for the women particularly; Garo women in Meghalaya. Eri-culture and weaving are also important activities for generating supplementary income and providing a much needed opportunity for women to contribute further to the family, especially for the elderly and the young mothers who are not able to go out to the fields. This traditional knowledge is passed down through generations (3). 
The loom is simple back strap one with a continuous horizontal warp consisting of six sticks serving the function of warp beam, lease rod, heald stick, beating sword and extra warp beam. The loom and its components are hand-made by the village women themselves. The heddles are made from string, tied on manually every time a new warp is put on the loom. The floor loom produces one scarf per warp, whereas the frame loom offers possibilities of increased production (5).

The distinctive costumes and apparels comprise wrappers and shawls, waistcloths and bodice, girdles, scarfs, skirts, aprons and lungis resplendent with skilful colour combination in their own fashion and style. The patterns in cloth are obtained by the necessary combination of different coloured threads in the warp and weft.

The embroidery is traditionally done on a handspun and handwoven eri silk shawl, creating the pattern by counting the warp threads. This embroidery technique is an expression of local cultural identity, and an important physical illustration of historic trading routes in the state of Meghalaya.

\section{Issues of Women Weavers in India}

Women weavers have also been at the receiving end of discrimination of all types. Whenever handloom sector is in crisis, the burden of carrying through the crisis is the most on women weavers, through increase in physical, psychological and social pressures. Their health condition is a major concern, as also their role in relations of production and also the future of girl children. While performing critical functions in production, their role in decision-making is rather poor.

\section{Wage Discrimination of Women Weavers}

Women lack direct access to wages since weaving is a household enterprise and men take the final product to the master weaver for sale. Weavers depend on master weavers for credit, raw material and market support. Master weavers in general are people who invest in production, and sell the products even in instances where women are paid wages for small, piece-meal activities like yarn-winding, sizing etc, these wages range from Rupees 10-15/- per day. Single and older women suffer more since they cannot take on labor-intensive activities and lack family support. Literacy levels in general are poor amongst weavers and particularly lower in girls and women.

Adolescent girls are also involved in weaving operations at the household levels and as paid wage-workers. There is no recognition to women's work as weavers, even though women play a major role in all pre-loom operations and take on labor-intensive activities. Women do not have access to government identity cards, except in cases where they are widowed or are members of the cooperatives (14).

\section{Technology upgradation: An Issue to Women Weavers}

The invention of the power loom, the recurrence of sweatshop manufacturing and a competitive global textile market was stripping handloom weavers of their market. The traditional handloom sector failed in the area of technological up gradation, value added product development, diversification and effective marketing management. The constant debts of the families, illness and other factors such as globalization, power looms and industrialization retained them at the lowest level of subsistence. Their low wages went to pay debts and forever they remained in poverty and deprivation. They toiled very hard, but the returns were very few and far between. 


\section{Suggestions}

To overcome the issues of women weavers some of the important suggestions are mentioned below:

The central and state government must take concerted and collective steps at multiple levels. These could include, for example, facilitation of easier access of these sectors to credit from banks and other financial institutions and the promotion of the products of these sectors in domestic and foreign markets.

Universities, corporate sector and Government departments should contribute by sponsoring - and themselves taking up - research that results in innovative technology to adapt and upgrade the traditional tools and designs of the local artisans and women weavers.

All concerned Ministries and Departments to stay vigilant and respond promptly to demand in existing and emerging markets.

The Government should provide alternative source of raw materials in order to ensure uninterrupted supply e.g. suta supply card, Dhaga ATM etc.

The Government should provide training facilities and special women oriented incentives to each and every worker in the unit for making better quality products.

The government should provide financial support for the widening of the unit. The textile policies have to be renewed.

Due to restless weaving activities, large numbers of women are suffering from gynaecological problems. In order to lessen the women casualties, free medical camps and mobile health centres be established in the handloom clusters in all parts of India, in particular government should concentrate the handlooms in hamlets and remote villages $(14,5)$.

The government has to find out alternative marketing sources to sell their products.

\section{Role of the Government}

In Meghalaya, three government departments primarily focus on women's issues: (1) the Meghalaya Social Welfare Department (MSWD), (2) the National Rural Health Mission (NRHM), and (3) the Women's Special Cell. Social Welfare's main focus is on the holistic development of Meghalaya society. It aims at the social and economic development of women, children, disabled individuals, and juvenile delinquents in the state. Currently, Social Welfare is trying to focus on making the village headmen understand that women's issues relating to domestic violence should not be handled by the village but instead should be reported and handed over to experts.

Weaving in Meghalaya is most important cottage based eco-friendly industries in the rural areas. This industry portrays the cultural ethos and rich heritage of the people of the State. In preserving and exhibiting the rich cultural identity and heritage, eco-friendly sericulture weavers of Meghalaya have come a long way in perfecting their art and designs with Prime Minister Narendra Modis ambitious project Make in India. Union Textiles Minister Smriti Irani Irani along with Chief Minister Mukul Sangma, had inaugurated Meghalayas first state-of-the-art apparel and garment making centre at Ampati. The Rs 14.26-crore project was commissioned under the North East Region Textiles Promotion Scheme, (NERTPS).

The co-operative consists of twenty five 
women artisans and weavers from the Garo and Hajong tribe. They used to go time to time through the professional training program with the leader of the co-operative with her daughter who will eventually take over the sustainable enterprise. This Dakmanda weaving tradition and culture, producing fine traditional handlooms wrap has gained acceptance and legitimisation across the region of Garo hills of Meghalaya, however, the weavers are still in need of a wider acceptance of their skill and craft that not only reveal that they are legitimate artisans, but also that their sustainable practices of using non-synthetic colouring and cottage industry that respects, trains and supports the workers needs to grow not only in the region, but globally(13).

In conclusion women are a large part of the work force in the weaving sector and women constitute over $50 \%$ of the artisans' sector. A considerable percentage of weavers and artisans belong to the Scheduled Castes and Tribes and religious minorities. This sector not only provides low investment income opportunities for families in the rural sector but it also supplements their incomes in offseason of Agriculture. Vitality in this sector checks migration and helps to keep traditional economic relationships intact. It is significant that the handlooms sector in India, with 24 lakh handlooms, provides employment to about 44 lakh persons and our handicrafts sector provides employment to about 70 lakh persons $(2,9)$. The Textile Sector provides largest employment opportunities next to Agriculture. However, it cannot be ignored that this sector, despite its wide production base, has been constrained in its growth. It has been disadvantaged by its inadequate access to credit, dependence on middlemen, inadequate availability of raw material, outdated technology and limited access to markets. The products in this sector remain vulnerable to competition from cheaper imports and machine made substitutes. These factors need to be addressed urgently, systematically and comprehensively and we must give more attention to development of capacity, skills, designs and infrastructure.

Traditional activities such as handicrafts and handloom still predominated the type of activities undertaken by the women entrepreneurs of Meghalaya. Majority of women entrepreneurs managed finance through their own sources. The study concludes that women of the region have enough potential to take up Handloom entrepreneurship as a career. Determined efforts from women entrepreneurs supported by congenial climate can bring about substantial results.

\section{References}

1. Sakuntala, N., (1999). Empowerment of Women: An Alternative Strategy for Rural India, Saga Publication India Pvt. Ltd, New Delhi. 255p.

2. Premsundar B.and Kannan, J. (2013) Women in Handloom Industry: Problems and Prospects, Journal of Economic and Business Review,1(1):3238.

3. Annual report, Ministry of textiles, (2012). International Journal of Business and Administration Research Review.2(7), Programme Evaluation Organization, Planning Commission, Government of India. New Delhi. Press Information Bureau Release, Ministry of Textiles, 2012.

4. Reddy D.N., (2013). Women handloom workers facing the brunt of economic reforms in Indie, Centre for Handloom Information and Policy Advocacy. https://www.nmew.gov.in/index.php?la $\mathrm{ng}=1$

5. Borah,A. and Goswami, B.K., (2012). Factors Influencing Wage Structure of 
Handloom Workers in Assam. Journal of Rural Development, 31:139-150.

6. Bonnie, B. J. and Harrison F. E. (2005), "Incidence and Duration of Unemployment Spells: Implications for Male-Female Wage Differentials", The Quarterly Review of Economics and Finance, 45, 824-847.

7. Cobb- Clark, D.A and Tan, M. (2011), "Noncognitive Skills, Occupational Attainment, and Relative Wages", Labour Economics, 18, 1-13.

8. Handloom Census of India 2012-13.

9. Kumar, S. (2012). Self- Help Group in Socio-Economic transformation with special reference to Coimbatore. International Journal of Research in Commerce, Economic and Management, 2 (9):87-93.

10. Bortamuly, A. B., Goswami, K., Hazarika, B. (2013). 'Determinants of Occupational Choice of Workers in the Handloom Industry in Assam. International Journal of Social Economics, 40 (12): 1041-57.

11. Singha, R. and Singha, S. (2020). Women's Empowerment through the
Silk Industry of Assam, India, and its underlying Economy. Journal of International Women's Studies, 21(5), 9-31.

12. Goswami, K.,Bhabesh, $\mathrm{H}$ andHandique, K.(2017). Determinants of financial risk attitude among the handloom microentrepreneurs in North East India. Asia Pacific Management Review. 22:168175.

13. Sinha. P. (2003). Centre for Industrial Relations and Human Resources.Indian Journal of Industrial Relations. 38(4): 425-443.

14. Raju. G. (2014) Empowerment ofwoman weavers through handloom industry-pros and cons. International Journal of Business and Administration Research Review.2(7): 98-103.

15. Bhabesh, H, Prashad, M. and Goswami, K. (2016). Adoption of modern weaving technology in the handloom microenterprises in Assam: A Double Hurdle approach. Technological forecasting and social change, 102:344-356.

\section{How to cite this article:}

Anupama Mishra, Puspita Das and Sangma, W. S. N. 2021. Handlooms Micro-enterprises for Empowerment of Women in Meghalaya. Int.J.Curr.Microbiol.App.Sci. 10(01): 2493-2500. doi: https://doi.org/10.20546/ijcmas.2021.1001.289 